\title{
ANALYSIS OF FACTORS RELATED TO FOOD SECURITY IN MALANG PROVINCE EAST JAVA
}

\author{
Ahmad Dedy Syathori ${ }^{1}$, Yayuk Yuliati ${ }^{2}$, Keppi Sukesih ${ }^{3}$, Ismulhadi ${ }^{4}$ \\ ${ }^{1}$ Center for Agricultural Training Ketindan, Malang, East Java, Indonesia \\ ${ }^{2}$ Brawijaya University in Malang, East Java, Indonesia \\ ${ }^{3}$ Brawijaya University in Malang, East Java, Indonesia \\ ${ }^{4}$ Agricultural high School in Malang, East Java, Indonesia \\ *corresponding author: dedybbppketindan @gmail.com
}

\begin{abstract}
Indonesia is one of the populated countries which still has high population growth. It will influence the food supply. The more the number of population, the demand for food will increase. Other food problems occur because of the limited resources available and the lack of infrastructure for farming activities. This study has the objective to analyze what factors are associated with food security in Malang. The method research approach used in this research is descriptive qualitative research approach. Sources of information or informants in this study are the agricultural extension field, the main actors, and public figures. Results of research on factors associated with food security in Malang is a factor of production, post-harvest, marketing, innovation, the participation of farmers, and behavioral changes. Activities to empower farmers program implemented should involve the participation of key actors and activities undertaken farmers' empowerment program should be based on the needs of the main actors.
\end{abstract}

Keywords: Food Security, Farmer Empowerment, Participation, Principal

\section{INTRODUCTION}

Food security is where the fulfillment of the conditions will be food for a nation to the individuals who reflect the availability of adequate food, both in quantity, quality, safe, diverse, nutritious, and evenly (Regulation of the Minister of Agriculture number 15 of 2015). Food security is a substantial issue that made the priority in solving the problems of hunger and malnutrition and become one of the main prerequisites for sustainable development (Grebmer et al., 2015).

The availability of Food Insecurity Center and the Ministry of Agriculture stated that the resistance situation in Indonesia in 2012 were 100 districts out of 349 districts in Indonesia have the potential food shortages (Ashari et al., 2012). Factor that causes food insecurity is the consumption rate of Indonesian still relies on the main food which is rice. Many efforts have been made by the government and various stakeholders in order to shift to the consumption pattern in addition to rice and seek other alternatives in food consumption (Ningsih, 2012).

A sector that has significant roles in food security in Malang is the agricultural sector. Each sub-district has the specific and potential different resources so that the management should be done in a systematic, comprehensive and integrated according to the conditions of the potential of each region. Currently food production Malang is still constrained by the presence of competition in the use and degradation of natural resources and human resources, the application of appropriate technologies that are not yet effective. If the problem cannot be anticipated well, it is feared could disrupt the balance of food Malang in short term and long term. The solution to overcoming the obstacles and challenges of development of food security, the development of the potential of agricultural resources should be optimized, in addition to the participation of the various elements will affect the availability of food, increasing food access both the physical and economic, as well as the absorption rate for food should be done in a balanced, which in turn will increase food security.

Based on data from the Malang Statistics document (2016), Malang has an area of $110.06 \mathrm{~km}^{2}$ with a population of 763.465 inhabitants. On the other hand, the rate of population growth in Malang per year over the last ten years by an average of $6.50 \%$. Malang is most populated region in EastJava province after Surabaya region; the food supply 
at Malang comes from domestic production and also outside the region, as an example the need of rice and vegetables still dependent on import from Batu, and Pasuruan, so the food availability should be a great concern to guarantee the availability of food. As the region at say, including urban areas, the use of land size for agricultural activities is very small.

Land conversion from agricultural land into housing and building construction is really the big challenge. This causes the sortage of food needs at Malang Regency. Based on the existing potential problem and challenges, this study aims to analyze the factors that are involved in food security development in Malang.

\section{RESEARCH METHODS}

\section{Places and Time}

The research was conducted in five sub-districts: Kedungkandang, Sukun, Klojen, Lowokwaru, Blimbing. This research is located in Malang, East Java Province. The time of the study is in April to September 2017.

\section{Research Approach}

This research is conducted using mostly qualitative data. The appropriate qualitative research approach used is the phenomenological approach because of the phenomenology associated with an understanding of how every day in our daily lives. Moreover, researchers used the phenomenological approach aims to interpret the factors associated with food security in Malang.

\section{Data Type}

Type of data collected in the research activities carried out and consists of primary data and secondary data. Primary data were obtained from 35 informants and secondary data obtained from the Department of Agriculture and Food Security of Malang, Bureau of Statistics Malang and local government of Malang.

\section{Informant Research}

Informants assigned snowball sampling technique to determine the respondents to follow information from informants before. The informants of this research are the department of agriculture and food security officers of Malang, an agricultural extension officers, the main actors and also local public figures.

\section{Data Collection Techniques}

Data collection techniques used in this study are (1) observation, (2) interviews, and (3) documentation. Validity used include triangulation. This is used to include data triangulation, triangulation of sources and triangulation methods.

\section{Data Analysis}

The process of data analysis in this study conducted in conjunction with the implementation of data collection. Data analysis were performed in this study, namely; data reduction, data presentation, and conclusion.

\section{RESULTS AND DISCUSSION Production Factor}

From the opinions of informants about the relationship of the factors of production for food security in Malang rated moderate. For more detail can be found in Table 1 below.

Table 1. Linkage with the Production Factor Food Security in Malang.

\begin{tabular}{|c|c|c|c|c|c|c|c|}
\hline \multirow{3}{*}{ No } & \multirow{3}{*}{ Production Factor } & \multicolumn{6}{|c|}{ Food Security } \\
\hline & & \multicolumn{2}{|c|}{ Availability } & \multicolumn{2}{|c|}{ Accessibility } & \multicolumn{2}{|c|}{ Absorption } \\
\hline & & Weights & Criteria & Weights & Criteria & Weight & Criteria \\
\hline \multirow[t]{2}{*}{1.} & SDA: & & & & & & \\
\hline & - Land & 10 & Low & 10 & Low & 10 & Low \\
\hline \multirow[t]{3}{*}{2.} & HR: & & & & & & \\
\hline & - Experience farm & 10 & Low & 10 & Low & 10 & Low \\
\hline & - Minimum & 30 & Average & 30 & Average & 30 & Average \\
\hline \multirow[t]{3}{*}{3.} & Capital: & & & & & & \\
\hline & - Capital own & 30 & Average & 30 & Average & 30 & Average \\
\hline & - Capital beyond & 30 & Average & 30 & Medium & 30 & Medium \\
\hline 4. & Management & 30 & Average & 30 & Average & 30 & Average \\
\hline
\end{tabular}

Source: Primary Data Processing, 2017

Based on Table 1 above states that the experience of farming and the land has a lower linkage, whereas age, capital and the management of moderate influence on food security in Malang, both in the availability, accessibility, and absorption of food. Production activities very important role in protecting the occurrence of both the level of food insecurity household and community level (Ghattas, 2013). Production activity can produce a much better production if supported by inputs used or commonly called the factors of production. Factors affecting the production of the large or small amount 
of production, in this research activity consists of the production factors of land, capital, management, and experience of farmers.

\section{Post Harvest}

Linkage of all items in food security, which are food availability, accessibility, and food utility related to post harvest activities in Malang are in high-rated categories, as shown in Table 2 below.

Table 2. Linkage Parameters Post Harvest with Food Security in Malang.

\begin{tabular}{cccccccc}
\hline \multirow{2}{*}{ No } & \multirow{2}{*}{ Post-Harvest } & \multicolumn{5}{c}{ Food Security } \\
\cline { 3 - 7 } & & \multicolumn{2}{c}{ Availability } & \multicolumn{2}{c}{ Accessibility } & \multicolumn{2}{c}{ Absorption } \\
\cline { 3 - 7 } & Weights & Criteria & Weights & Criteria & Weight & Criteria \\
\hline 1. & Sorting & 60 & High & 60 & High & 60 & High \\
2. & Packing & 30 & Average & 30 & Average & 30 & Average \\
\hline Source: Primary Data Processing, 2017 & & & & &
\end{tabular}

Conducted post-harvest handling of informants in Malang namely cleaning and sorting, while the activity of packing the only purpose is to facilitate the transportation activities and to attract consumers for buying the products. Post-harvest handling activities are very important, not only aim to maintain the quality of a product but also it can affect the level of farmers' income. Article 31 of Law No. 12 of 1992 in the post-harvest crop cultivation is an activity that involves cleaning, stripping, sorting, preservation, packaging, storage, quality standardization, and transportation results.
Yulida (2012) stated that through the appropriate post-harvest handling can increase farmers' income by up to $30 \%$ without having to raise the selling price of a product that typically relies on market mechanisms.

\section{Marketing}

Based on informants' opinion, marketing linkages with food security are rated moderately. Here the value of each marketing parameters is shown in Table 3 below.

Table 3. Linkage Marketing and Food Security in Malang

\begin{tabular}{cccccccc}
\hline \multirow{2}{*}{ No } & \multirow{2}{*}{ Marketing } & \multicolumn{5}{c}{ Food Security } \\
\cline { 3 - 7 } & & \multicolumn{2}{c}{ Availability } & \multicolumn{2}{c}{ accessibility } & \multicolumn{2}{c}{ Absorption } \\
\cline { 3 - 7 } & & Weights & Criteria & Weights & Criteria & Weight & Criteria \\
\hline 1. & Marketing Channels & 30 & Average & 30 & Average & 30 & Average \\
2. & Promotion & 10 & Low & 10 & Low & 10 & Low \\
3. & Sales & 30 & Average & 30 & Average & 30 & Average \\
\hline
\end{tabular}

Source: Primary Data Processing, 2017

Based on Table 3 above that the marketing and sales channel linkage to food security both the availability, accessibility, and utility of food rated moderately, while promotional is assessed by the low category. Marketing activities results of agricultural products in Malang, the average includes categories of short marketing channels, because most farmers sell their crops directly to consumers. This activity will give benefit to farmers as producers because the higher price will be obtained.

The more the length of the marketing chain, the marketing costs will increase. This will result in the increasing number of marketing margin so the impact on prices received by farmers as producers increasingly smaller. According to Kotler (2003), the number of parts received by farmers is affected by the level of processing, transportation costs, durability or quality and quantity of production.

Sales is a source of income, the greater the sales, the greater the revenue producers. Promotional activities as an effort in marketing strategy, promotional activities have not been made through the use of social media, in general consumers informed about product obtained from sources per person. Kotler (2003), reveals that there are other activities in the marketing process are among others that the sale, purchase, collection, storage, selection, shipping/transport, service after the purchase, financing, information sharing, coordination and payment channels. In marketing activities in this research seen from the many actors involved in the marketing, promotion, and sales. 


\section{Innovation}

Based on the results of 35 informants, it can be seen that there is a change in the speed level receive an innovation after farmer empowerment program. Such changes can be described as follows.

Table 4. Farmers Group Based Innovations Adoption Speed

\begin{tabular}{|c|c|c|c|c|c|}
\hline \multirow{3}{*}{ No } & \multirow{3}{*}{ Level Group Adoption Speed } & \multicolumn{4}{|c|}{ Empowerment Program } \\
\hline & & \multicolumn{2}{|c|}{ Before } & \multicolumn{2}{|c|}{ After } \\
\hline & & $\begin{array}{l}\text { Number of } \\
\text { Informants }\end{array}$ & $\%$ & $\begin{array}{l}\text { Number of } \\
\text { informants }\end{array}$ & $\%$ \\
\hline 1. & Innovators & 2 & 5.71 & 2 & 5.71 \\
\hline 2. & Pioneer / Pioneer & 3 & 8.57 & 5 & 14.29 \\
\hline 3. & Early Followers & 10 & 28.57 & 19 & 54,26 \\
\hline 4. & Followers end & 14 & 40.00 & 6 & 17.14 \\
\hline 5. & Group conservative / traditional & 6 & 17.14 & 3 & 8.57 \\
\hline & Total & 35 & 100 & 35 & 100 \\
\hline
\end{tabular}

Source: Primary Data Processing, 2017

From Table 4 above can be seen that before any program taken for empowering farmers, groups of innovation adoption speed level more in the group of followers of the end as much as $40 \%$. Following the program of activities to empower farmers through training, education, provision of capital and mentoring, the level of innovation adoption rate increased to a group of informant early followers as much as $54.26 \%$. This shows that by doing activities can change the farmers' empowerment program from being late followers to become an early follower.
Assessment of informants against innovation linkages with food security in Malang which includes the availability, accessibility, and utility of food, can be seen from the type and the nature of innovation that each of them received. Parameter type and nature of innovation have high criteria, which means that the kind of innovation physical and non-physical, nature of innovation which includes profits, compliance, complexity, temptation and easier to see, have a high relevance to food security in Malang. For greater clarity and detail can be seen in Table 5 below.

Table 5. Parameters Innovation Linkages to Food Security in Malang

\begin{tabular}{|c|c|c|c|c|c|c|c|}
\hline \multirow{3}{*}{ No } & \multirow{3}{*}{ Innovation } & \multicolumn{6}{|c|}{ Food Security } \\
\hline & & \multicolumn{2}{|c|}{ Availability } & \multicolumn{2}{|c|}{ Accessibility } & \multicolumn{2}{|c|}{ Absorption } \\
\hline & & Weights & Criteria & Weights & Criteria & Weight & Criteria \\
\hline 1. & Type of innovation: & & & & & & \\
\hline \multirow{8}{*}{2.} & a. Physical & 60 & High & 60 & High & 60 & High \\
\hline & b. Non-Physical & 60 & High & 60 & High & 60 & High \\
\hline & Nature of Innovation: & & & & & & \\
\hline & a. Advantages & 60 & High & 60 & High & 60 & High \\
\hline & b. Compliance & 60 & High & 60 & High & 60 & \\
\hline & c. High-complexity & 60 & High & 60 & High & 60 & High \\
\hline & d. Ketercobaan & 60 & High & 60 & High & 60 & High \\
\hline & e. Visits Easy & 60 & High & 60 & High & 60 & High \\
\hline
\end{tabular}

Source: Primary Data Processing, 2017

Innovation according to the informant has a very important role because farming can help increase productivity in agriculture. The participation rate of the informant in achieving food security can be influenced by the attitude towards innovation informant received. Rate informant against the innovation seen on the type and nature of innovation. How cultivation systems and cultivation vertikultur using polybag media is a form of innovation that the informant received. The process of innovation adoption informant in Malang are divided into groups according to the degree of adoption receiver innovation or speed in receiving a given innovation and innovation in accordance with the ethical, aesthetic, intellectual, social and religious.

Kurnia (2011) states that an innovation can agree or disagree with the farmers, from the aspects of (1) the values of sociocultural, (2) the ideas that have been introduced previously, and/or (3) the farmers' need for innovation. Innovation is not acceptable to society if innovation is judged to be profitable, so an innovation that will be given should benefit both the technical aspects and economic aspects (Kustiyah, 2011).

\section{Farmers Participation}

Participation of farmers in achieving food security in Malang can be seen from the frequent absence of 
the farmers involved in food security programs. Results of interviews with informants that farmers still frequently follow the activities carried out in empowerment programs such as counseling, training and other activities that are closely related to the program such as exhibitions. Farmers do the participation with the level of consciousness themselves without any coercion from any party. With the involvement of farmers can benefit, both from the aspect of knowledge as well as economic aspects.

Here is the opinion of the interrelationships parameter informant participation of farmers with food security in Malang can be seen in Table 6 below.

Table 6. Parameter Linkages to Food Security Farmers Participation in Malang.

\begin{tabular}{|c|c|c|c|c|c|c|c|}
\hline \multirow{3}{*}{ No } & \multirow{3}{*}{ Participation Farmer } & \multicolumn{6}{|c|}{ Food Security } \\
\hline & & \multicolumn{2}{|c|}{ Availability } & \multicolumn{2}{|c|}{ Accessibility } & \multicolumn{2}{|c|}{ Absorption } \\
\hline & & Weights & Criteria & Weights & Criteria & Weight & Criteria \\
\hline 1. & $\begin{array}{l}\text { The intensity of the } \\
\text { activities }\end{array}$ & 60 & High & 60 & High & 60 & High \\
\hline 2. & Quality participation & 30 & Average & 30 & Average & 30 & Average \\
\hline 3. & Quality benefits & 30 & Average & 30 & Average & 30 & Average \\
\hline
\end{tabular}

Source: Primary Data Processing, 2017

Participation of farmers in Malang which includes the intensity of the activity has a high relevance, while the quality of participation and the quality of the benefits of having links with food security being good in the availability, accessibility, and absorption of food. Farmer participation in the development program covering the entire process from beginning to end, either in the planning, implementation, utilization and evaluation results (Abiona, 2013). In the implementation of farmer empowerment, participation should be used as an indicator by policymakers to devise a plan to address the various problems faced by the farmers, because participation can determine the quality of life of farmers (Lyndon, 2011).

\section{Changes in Behavior}

Efforts in achieving food security in Malang, according to the informant changes in behavior have high relevance to food security both in the provision, accessibility, and absorption of food. Linkage behavior change with food security can be seen from each of its parameters, as shown in Table 7 as follows.

Table 7. Behavior Change Linkages with Food Security in Malang

\begin{tabular}{llcccccc}
\hline & \multirow{6}{*}{ No } & Behavior in Changes & \multicolumn{2}{c}{ Food Security } \\
\cline { 3 - 7 } & & & Availability & \multicolumn{2}{c}{ Accessibility } & \multicolumn{2}{c}{ Absorption } \\
\cline { 3 - 7 } & & Weights & Criteria & Weights & Criteria & Weight & Criteria \\
\hline 1. & Knowledge & 60 & High & 60 & High & 60 & High \\
2. & Attitude & 60 & High & 60 & High & 60 & High \\
3. & Skills & 60 & High & 60 & High & 60 & High \\
\hline
\end{tabular}

Source: Primary Data Processing, 2017

Assessment of behavior change in this study is based on the opinion of several informants who have joined to farmers empowerment program. These behavioral changes are experienced by informants before and after getting farmers empowerment program activities judged from the growing media making techniques, the manufacturing technique nursery, cultivation techniques, post-harvest techniques, marketing of agricultural products, agricultural products, and processing techniques.

Mardikanto (2009), states that behavioral changes through the learning process is relatively slow, but changes relatively more enduring. The behavior of farmers in the farm will affect the level of a productivity. Changes in behavior are one indicator of the quality of human resources in an effort to absorb the technology or innovation to increase productivity and living standards.

\section{CONCLUSION}

The factors associated with food security in Malang are production, post-harvest, marketing, innovation, the participation of farmers, and behavioral changes. The behavioral changes experienced by informants before and after getting farmers empowerment program activities are based on mastery informants growing media making techniques, the manufacturing technique nurseries, crop cultivation 
techniques, post-harvest techniques, marketing of agricultural products, agricultural products, and processing techniques.

Farmer empowerment program is still needed to be held in the future, but the success of such activities depends on the degree of participation of key actors and activities which are undertaken farmer in the empowerment program and it should be based on suitability to the needs of the main actors.

\section{REFERENCES}

Abiona, 2013. Excluding the Excluded: The Challengers of Sustainability in Government-Driven Re-Construction and Development Policy and Practice in Sout Western Nigeria (October 28, 2013). OIDA International Journal of Sustainable Development, Vol.6, No. 2, pp.83-92, 2013.

Ashari et al., 2012. Potential and Prospects of Land Use Yard to Support Food Security. Journal of agro-economic Research Forum, 30 (1), 13-30.

The Central Bureau of Statistics, 2016. Total Poverty and Unemployment in Indonesia: RI BPS. Jakarta.

BurhanMungin, 2007. Qualitative Research. Jakarta: PT FajarInterpratama Offset.

Edi Suharto, 2005. Building Societies Empowering People. Bandung: PT RefikaAditama.

AdiFahrudin, 2012. Participation Empowerment Capacity Building Society. Bandung: Humanities.

FAO, 2012. Imaging A World Free From Hunger: Ending Hunger and Malnutrition And Ensuring Food and Nutrition Security. Paper presented at the UN System Task Team on the Post-2015 UN Development Agenda, May 2012.

Ghattas, 2013. Gender and Awareness: The Missing Element in the Third World Development Project, in Changing Perceptions, adapted by UNICEF as the Policy Framework for Development Project.

Grebmer et al., 2015. Armed Conflict and the Challenge of Hunger. Paper presented at the Global Hunger Index, October 2015.
Kotler, Marketing Management 2003. Volume 2. Issue 10. SADDLE Upper River, Prentice Hall. Inc. New Jersey.

Kurnia, 2011. Village Community Development, Principles, Policy, and Management, Media Widya Mandala, Yogyakarta.

Kustiyah, 2011. Development GerakanBudaya courtyard to Support Independent Natural Health (BUMIKITA) in the Village of Situ Gede, Bogor subdistrict West, the Municipality Bogor. Fakultas Forestry. Bogor Agricultural Institute. Bogor.

Lyndon, 2011. Guidelines for Sensory Analysis. Maryland. Open Publish.

Mardikanto T, 2015. Models of Community Empowerment. Eleven universities in March Solo.

Ningsih RD, 2012. The courtyard of Land Arrangement to Enhance Food Consumption PengenekaragamanGuntung Umbrella Village, Banjarbaru, South Kalimantan. Paper presented at the Proceedings of the National Seminar 2012: Optimization of Land courtyard for the Improvement of Public Economy and Agricultural Development, Semarang, 6 November 2012.

Regulation of the Minister of Agriculture Number 152015 Legal Documentation and Information Network for Educational Agency of the Republic of Indonesia. (Http://bkp.pertanian.go.id/tinymcpuk/gamb ar/file/PERMENTAN_15.pdf), accessed 14 July 2017.

Sugiyono, 2012. Qualitative and Quantitative Research Methods in Social Research. Alfabeta. Bandung.

Act No. 12 of 1992. Plant Cultivation System. (Http://ditjenbun.pertanian.go.id/gambar /file/UU_12.pdf)accessed on July 14, 2017.

Yulida R, 2012. Contributions Farm Land courtyard of the Economic Farmer Households in the district of KerinciPelalawan. Indonesian Journal of Agriculture Economics (IJAE), 3 (2), 132-154. 
